\title{
Ecological field data collection
}

\author{
Hayley Clements, ${ }^{1}$ Karen Esler, ${ }^{2}$ Dominic A.W. Henry, ${ }^{3,4}$ \\ Penelope Mograbi, ${ }^{5}$ Albert Norström ${ }^{6}$ and Chevonne Reynolds ${ }^{7,8}$
}

\begin{abstract}
'CENTRE FOR SUSTAINABILITY TRANSITIONS, STELLENBOSCH UNIVERSITY, STELLENBOSCH, SOUTH AFRICA
${ }^{2}$ DEPARTMENT OF CONSERVATION ECOLOGY AND ENTOMOLOGY AND CENTRE FOR INVASION BIOLOGY,

STELLENBOSCH UNIVERSITY, STELLENBOSCH, SOUTH AFRICA

${ }^{3}$ STATISTICS IN ECOLOGY, ENVIRONMENT AND CONSERVATION, DEPARTMENT OF STATISTICAL SCIENCES, UNIVERSITY OF CAPE TOWN, CAPE TOWN, SOUTH AFRICA

${ }^{4}$ ENDANGERED WILDLIFE TRUST, JOHANNESBURG, SOUTH AFRICA ${ }^{5}$ DEPARTMENT OF ENVIRONMENTAL SCIENCE, RHODES UNIVERSITY, MAKHANDA, SOUTH AFRICA ${ }^{6}$ STOCKHOLM RESILIENCE CENTRE, STOCKHOLM UNIVERSITY, STOCKHOLM, SWEDEN ${ }^{7}$ FITZPATRICK INSTITUTE OF AFRICAN ORNITHOLOGY, DST-NRF CENTRE OF EXCELLENCE, UNIVERSITY OF CAPE TOWN, CAPE TOWN, SOUTH AFRICA

${ }^{8}$ ANIMAL, PLANT AND ENVIRONMENTAL SCIENCES, UNIVERSITY OF THE WITWATERSRAND, JOHANNESBURG, SOUTH AFRICA
\end{abstract}

\section{Key methods discussed in this chapter}

Measuring faunal and floral diversity and population structure: Point counts and survey grids, transects, distance and plotless sampling, quadrats, capture and mark-recapture Measuring abiotic conditions: Abiotic environmental sampling, core sampling Measuring ecological processes: Telemetry, isotope and genetic analysis

\section{Connections to other chapters}

Systems scoping can be used to define system boundaries for ecological data collection (Chapter 6). To explore social-ecological interactions, ecological field data are often paired with social data-collection methods such as interviews and surveys (Chapter 7) or participatory data collection (Chapter 8), and analysed using statistical analysis (Chapter 18), network analysis (Chapter 23), spatial analysis (Chapter 24) or models (Chapters 26-28 and 31).

\section{Introduction}

Ecology (the study of the relations of organisms to one another and their environment) has a well-established and extensive set of field data-collection methods (Sala et al. 2000; Henderson 2003; Wheater, Bell, and Cook 2011) that have been developed to both advance ecological theory (e.g. optimal foraging theory, theory of island biogeography) and address practical problems (e.g. conservation planning, monitoring ecological restoration). Although ecological field data-collection methods continue to be predominantly developed and used in 


\begin{tabular}{|c|c|}
\hline \multicolumn{2}{|c|}{ SUMMARY TABLE: ECOLOGICAL FIELD DATA COLLECTION } \\
\hline DISCIPLINARY BACKGROUND & KNOWLEDGE TYPE \\
\hline $\begin{array}{l}\text { The methods in this chapter are derived } \\
\text { from or have most commonly been used in: } \\
\text { Ecology, Zoology, Botany, Conservation } \\
\text { Biology }\end{array}$ & $\begin{array}{l}\text { The methods in this chapter are primarily } \\
\text { used to generate the following types of } \\
\text { knowledge: } \\
\text { - Descriptive } \\
\text { - Exploratory }\end{array}$ \\
\hline RESEARCH APPROACH & PURPOSE OF METHOD \\
\hline $\begin{array}{l}\text { The methods in this chapter originate } \\
\text { from or most commonly adopt the } \\
\text { following research approaches: } \\
\text { - Analytical/objective }\end{array}$ & $\begin{array}{l}\text { The most common purposes of using the } \\
\text { methods in this chapter are: } \\
\text { - Data collection/generation }\end{array}$ \\
\hline TEMPORAL DIMENSION & SYSTEMIC FEATURES AND PROCESSES \\
\hline $\begin{array}{l}\text { The methods in this chapter are most } \\
\text { commonly applied to the following } \\
\text { temporal dimensions: } \\
\text { - Present (typically within the last } \\
5-10 \text { years) } \\
\text { - Recent past (post-1700s) }\end{array}$ & \multirow{3}{*}{$\begin{array}{l}\text { While most methods can do many } \\
\text { things, the methods in this chapter are } \\
\text { particularly good (i.e. go-to methods) for } \\
\text { addressing the following: } \\
\text { - SES components and linkages } \\
\text { - Diversity } \\
\text { - Social-ecological dependence } \\
\text { and impact }\end{array}$} \\
\hline SPATIAL DIMENSION & \\
\hline $\begin{array}{l}\text { The methods in this chapter are primarily } \\
\text { either or both: } \\
\text { - Explicitly spatial } \\
\text { The methods in this chapter are most } \\
\text { commonly applied at the following } \\
\text { spatial scales: } \\
\text { - Local } \\
\text { - Regional (provincial/state to } \\
\text { continental) } \\
\text { - Multiple places/sites around the world }\end{array}$ & \\
\hline
\end{tabular}


the biological sciences (e.g. ecology, zoology, botany), many of these methods are also useful to social-ecological systems (SES) research.

Ecological field methods are largely quantitative and assume that researchers and research methods are entirely objective (i.e. the researcher is an independent observer who does not have an influence on the data that are collected). Studies based on ecological field methods are therefore assumed to be replicable - if a different researcher went to the same site and followed the same method, it should be possible to obtain the same study results (this assumption is common for many scientific methods, but not made by some other methods used in SES research, such as facilitated dialogues (Chapter 9) and scenarios (Chapter 11)). Ecological field methods are often scale sensitive - the results obtained depend on the method grain (minimum spatial resolution of the data collected, e.g. quadrat size) and extent (e.g. study area). Application of these methods therefore assumes that the appropriate spatial scale is being studied, which will depend on the questions being asked and the phenomenon under consideration (Wu et al. 2002). Study scale usually increases from the study of individuals and populations to communities and ecosystems.

\section{SES problems and questions}

Ecological field methods can be used to understand how human activities (e.g. resource use, land-use change, conservation actions) influence the ecological elements and processes on which human well-being depends. These ecological elements and processes provide ecosystem services such as climate regulation, food production, sense of place, recreation and relaxation. Ecological field methods can be used to understand the influence of ecological patterns and processes on social outcomes of interest (e.g. how does species composition influence the cultural benefits that people receive from a protected area? (Cumming and Maciejewski 2017)), and vice versa (e.g. what social, institutional and environmental conditions give rise to ecosystems that are in a substantially better condition than expected? (Cinner et al. 2016)). Some studies focus specifically on the interactions between ecological and social processes and outcomes (e.g. how has marine resource harvesting affected the ecosystem, and what are the consequences for local harvesters' livelihoods and economy over time? (Nordlund et al. 2010)).

The consideration of ecological patterns and processes is critical to understanding SES. The risk of a lake shifting from a clear-water state (desirable for drinking, fishing and recreation) to a turbid-water state (i.e. eutrophic, undesirable state) when exposed to anthropogenic nutrient inputs can be influenced by the size, depth and macrophyte density of the lake (Genkai-Kato and Carpenter 2005), for example. This is known as a regime shift. Similarly, the sustainability of fuelwood harvesting, a crucial provisioning ecosystem service in the developing world, is influenced not only by harvester demand and selectivity but also by ecosystem response, such as the regenerative potential of woody vegetation (Swemmer, Mashele, and Ndhlovu 2019). Ecological data are also used to understand and guide natural resource management and are especially effective when contextualised with large-scale data (Edgar et al. 2016). Systems thinking, for example, has promoted ecosystem-based fisheries management (Curtin and Prellezo 2010), recognising that the sustainability of fisheries depends on species-rich and functionally diverse communities that maintain ecological functioning (Nyström et al. 2008).

Ecological field data are by themselves insufficient to answer SES research questions; other methods need to be paired with ecological approaches to provide insight into the interactions of the ecological aspects with social aspects of the system (e.g. interviews - see Chapter 7; land-use maps - see Chapter 24; census data - see Chapter 25). Ecological field data are closely coupled with 
experimental design and appropriate statistical analysis (Chapter 18); thus, key reference textbooks often combine both field data collection and statistical analysis (e.g. Quinn and Keough 2002; Kent 2011). To understand feedbacks and dynamics in SES, ecological field data can also be used to parameterise models (i.e. inform the relationships that go into the model), such as agent-based models (see Chapter 28) or ecosystem service models (see Chapter 31) (e.g. Perez, Eun-kyeong, and Sengupta 2018). It can also be used in network analyses (see Chapter 23) (e.g. Hong et al. 2013).

\section{Brief description of key methods}

Ecological field methods can be used to quantify faunal and floral species richness and abundance (diversity) and population structure across a landscape/seascape or an environmental gradient (e.g. in different land uses, habitats, climates or management regimes). If the study is repeated over time, ecological field methods can be used to assess community and population dynamics (e.g. the process of change and development and the drivers of these dynamics). Other methods quantify abiotic conditions (e.g. water quality, erosion), or focus on ecological processes (e.g. dispersal or predation). A combination of faunal, floral and abiotic methods is often necessary to assess ecosystem function and processes. Table 6.1 provides a summary of key methods used in ecological field data collection.

\section{Limitations}

It can be challenging to 'bound the system', or to decide how large a sample area or sample size is necessary to identify trends, or to choose the resolution at which to collect data (e.g. size of quadrat or survey grid; length and number of transects). The appropriate scale of analysis depends on the question or taxa of interest (Wu et al. 2002). At fine spatial scales, for example, the presence of water drives elephant distribution, while at larger scales the presence of available forage drives elephant distribution (De Knegt et al. 2011). Systems scoping can be useful for defining study boundaries (Chapter 5). For some studies, it will also be important to collect data at the correct time of day and/or year (e.g. at night for nocturnal animals, or during breeding season).

Long-term collection of ecological data may be necessary to detect meaningful trends. This can be a limitation due to funding constraints and/or the short-term nature of many research projects that may be mismatched with the longer time scales of many ecological processes. The measurement of trends across space instead of through time ('space-for-time substitution') can sometimes be used to overcome this limitation. Data are collected across a large and diverse area (i.e. space) to understand drivers of species occurrence and abundance (i.e. time) (Edgar et al. 2016). Data can sometimes be collected from sites with different amounts of time elapsing since an event (e.g. disturbance, restoration or protection) to understand how the event has influenced changes in species occurrence and abundance.

Undertaking field data collection over large spatial areas or long temporal periods can be resource and time intensive, particularly for SES research when social data are often being collected concurrently. Consequently, the number of variables measured in the field may be insufficient to identify core variables or drivers of variation (see also Chapter 18). Direct methods such as point counts and quadrat surveys can have practical limitations (e.g. height measurements of extremely tall trees, measuring on steep slopes), whereas indirect methods such as camera traps, GPS tracking and satellite-derived measurements can present technical challenges (e.g. calibration, hardware, software). 
Table 6.1 Summary of key methods used in ecological field data collection

\begin{tabular}{|c|c|c|}
\hline Method & escription & References \\
\hline \multicolumn{3}{|c|}{ MEASURING FAUNAL AND FLORAL DIVERSITY AND POPULATION STRUCTURE } \\
\hline $\begin{array}{l}\text { Point counts } \\
\text { and survey grids }\end{array}$ & $\begin{array}{l}\text { Point counts and survey grids are used to } \\
\text { inventory and monitor faunal richness and } \\
\text { abundance (typically for highly visible and/or } \\
\text { audible organisms, such as reef fish or birds). A } \\
\text { trained observer records all focal taxa seen or } \\
\text { heard from a point-count station over a set time } \\
\text { period. This method can also be undertaken by } \\
\text { camera trap and acoustic arrays (especially for } \\
\text { birds and bats), which are typically positioned } \\
\text { across a survey grid. }\end{array}$ & $\begin{array}{l}\text { Key introductory text } \\
\text { Wheater, Bell, and } \\
\text { Cook } 2011 \\
\text { Applications to SES } \\
\text { Daw, Robinson, and } \\
\text { Graham 2011; } \\
\text { Jouffray et al. 2014; } \\
\text { Cinner et al. 2016; } \\
\text { Cumming and } \\
\text { Maciejewski } 2017\end{array}$ \\
\hline $\begin{array}{l}\text { Transects, } \\
\text { distance } \\
\text { sampling } \\
\text { and plotless } \\
\text { methods }\end{array}$ & $\begin{array}{l}\text { Transects, distance sampling and plotless } \\
\text { methods are used to assess faunal or floral } \\
\text { richness and abundance along transects, } \\
\text { frequently spanning an environmental } \\
\text { gradient. The transect can be walked, swum or } \\
\text { driven, depending on the taxa of interest. Video } \\
\text { transects and aerial surveys can also be used. } \\
\text { Flora identified visually is counted and measured, } \\
\text { normally along a length of tape where vegetation } \\
\text { is recorded at set intervals. Fauna can be identified } \\
\text { visually, through acoustics (e.g. cetaceans or } \\
\text { bats) or based on tracks and signs. Distances } \\
\text { to observed fauna along the transect are used } \\
\text { to estimate abundance, based on the statistical } \\
\text { assumption that the probability of detecting an } \\
\text { animal decreases as its distance from the } \\
\text { observer increases. Plotless sampling methods are } \\
\text { used to calculate densities of large species that are } \\
\text { dispersed (e.g. point-centred quarter method). }\end{array}$ & $\begin{array}{l}\text { Key introductory texts } \\
\text { Henderson 2003; } \\
\text { Kent 2011; } \\
\text { Wheater, Bell, and } \\
\text { Cook } 2011 \\
\text { Applications to SES } \\
\text { Chanda et al. 2003; } \\
\text { Ticktin, Whitehead, and } \\
\text { Fraiola 2006; } \\
\text { Edgar et al. 2014; } \\
\text { Ward et al. 2018 }\end{array}$ \\
\hline $\begin{array}{l}\text { Quadrat } \\
\text { sampling }\end{array}$ & $\begin{array}{l}\text { Quadrat sampling is used to assess faunal or floral } \\
\text { richness and abundance in an area by surveying } \\
\text { randomly or systematically distributed quadrats } \\
\text { (sometimes called plots). A quadrat is a frame } \\
\text { (traditionally square) used as a standard unit of } \\
\text { area. The quadrat is placed multiple times in } \\
\text { the study area and a trained observer records } \\
\text { all focal taxa seen. The patterns of species } \\
\text { occurrence in the sampled area are assumed to } \\
\text { be representative of the entire area. It is most } \\
\text { appropriate for sessile or slow-moving organisms } \\
\text { such as plants or some aquatic animals in } \\
\text { intertidal zones. }\end{array}$ & $\begin{array}{l}\text { Key introductory texts } \\
\text { Sala et al. 2000; } \\
\text { Henderson 2003; } \\
\text { Kent 2011; } \\
\text { Wheater, Bell, and } \\
\text { Cook } 2011 \\
\text { Applications to SES } \\
\text { Ticktin, Whitehead, and } \\
\text { Fraiola 2006; } \\
\text { Andersson, Barthel, and } \\
\text { Ahrné 2007; } \\
\text { Nordlund et al. 2010; } \\
\text { Mandle, Ticktin, and } \\
\text { Zuidema 2015 }\end{array}$ \\
\hline
\end{tabular}


Hayley Clements et al.

Table 6.1 (Continued)

\begin{tabular}{lll}
\hline Method & Description & References \\
\hline $\begin{array}{l}\text { Capture and } \\
\text { mark-recapture }\end{array}$ & Fauna is trapped and can be marked and recaptured to & Key introductory text \\
& $\begin{array}{l}\text { estimate abundance, survival probability and persistence. } \\
\text { Methods for trapping vertebrates include using Sherman }\end{array}$ & Cook 2011 \\
& live trapping (rodents), mistnetting and ringing (birds), & Applications to SES \\
& pitfall trapping (reptiles and amphibians), phyke or & Sutaria 2009; \\
& seine netting and electro-fishing (fish). Indirect capture & Mintzer et al. 2013 \\
& methods such as DNA analysis of scats or camera & \\
& trapping are also used for capture-recapture methods. & \\
& Methods for trapping invertebrates include pitfall traps, & \\
& pan traps (pollinators), hand nets (marine invertebrates), & \\
& light traps (nocturnal insects) and soil samples. &
\end{tabular}

\section{MEASURING ABIOTIC CONDITIONS}

Abiotic Abiotic environmental sampling is used to measure environmental abiotic properties of the environment, such as water sampling quality (e.g. pH, nutrient load, presence of heavy metals), soil moisture and respiration, and seismic activity. Abiotic components such as soil can be key determinants of plant species composition, productivity and responses to disturbances such as drought. Landscape functional analysis is a standardised assessment to measure rangeland function using abiotic indicators together with biotic indicators. Abiotic sampling is often performed along an environmental gradient.

Core sampling Sediment cores are extracted by drilling into the (see also Chapter 25) earth's crust with long cylinders, usually in wetlands or the ocean. Tree, ice and coral cores can also be obtained. These cores are dated and analysed to provide insights into the historical climate and biotic conditions. Sediment and ice cores are also used for fossil pollen and charcoal records, and stable isotope analysis.
Key introductory texts

Sala et al. 2000;

Tongway and Hindley 2004;

Tan 2005;

Wheater, Bell, and Cook 2011

Applications to SES

Genkai-Kato and

Carpenter 2005;

Addison et al. 2013;

Read et al. 2016

Key introductory text Smith 1987

Applications to SES

Dearing et al. 2012;

Forbes, Gillson, and

Hoffman 2018

\section{MEASURING ECOLOGICAL PROCESSES}

Telemetry Telemetry is used to measure the movement, dispersal or habitat use of species by tracking animals with the use of global positioning system (GPS) collars, radio-tags, a global system for mobile communications (GSM) or even fluorescent dyes, radioactive markers and drones.

$\begin{array}{ll}\text { Isotope and } & \text { Isotope analysis is used to understand a variety } \\ \text { genetic analysis } & \text { of physiological processes (e.g. photosynthetic }\end{array}$ genetic analysis pathways, water-use efficiency and water nitrogen fixation) and food web studies. Genetic analysis can be used to assess population dynamics (e.g. sourcesink dynamics), predation and the consequences of harvesting.
Key introductory text Hebblewhite and Haydon 2010

Applications to SES Johansson et al. 2015; Miguel et al. 2017

Key introductory texts Fry 2006;

Kress et al. 2015 Applications to SES Villasante 2012; Alexander et al. 2018; Minnie et al. 2018; Kemp et al. 2019 
Some field collection methods such as camera trapping, underwater video transects and telemetry can generate extremely large datasets. The analysis of these data can require specialised statistical, programming or modelling skills, as well as adequate computing power. In contrast, some field collection methods may also only generate small sample sizes (e.g. censuses of large predators, or endangered species), which may present challenges for statistical analyses.

Studies can be limited by the lack of a control or counterfactual; for example, it is difficult to say with certainty that a protected area was effective in protecting species unless a similar unprotected site has also been surveyed (Pressey, Visconti, and Ferraro 2015). Experimental design (especially sample replication and site randomisation) that ensures replicability is important to avoid 'pseudoreplication' - a process where artificially inflated replicates compromise the statistical validity of conclusions drawn from the analysis of field data.

\section{Resource implications}

Some ecological field methods require highly specialised knowledge and technology to identify species. Field guide books and online species identification apps can help in this regard, but many species look extremely similar, or are only identifiable in certain seasons (e.g. some grasses are only identifiable when they are flowering), under a microscope (e.g. some insects) or require genetic approaches (e.g. coral identification). Involving taxonomic experts and/or people with local knowledge in the data collection can be useful.

Some field methods are expensive, particularly those that make use of modern technology such as camera traps, genetic sampling and acoustic equipment. Ethical clearance also needs to be obtained for data-collection methods that capture animals. The presence of dangerous animals at a field site (e.g. elephants, lions) can constrain data collection or necessitate the use of armed rangers. Handling of dangerous animals such as snakes also requires special training. Fuel and vehicle maintenance can also become a large expense for extensive data collection.

The researcher often needs to obtain a permit before undertaking the study of certain species, or requires permission from the site landholders before being allowed access to field sites. Field studies over large areas may require permission from a diverse range of landholders or other stakeholders (e.g. national park agencies, farmers, forestry companies, local communities).

\section{New directions}

While some ecological field data collection techniques have been used widely in SES research (e.g. point counts and quadrats), other methods are less commonly used in interdisciplinary research (e.g. core sampling, isotope and genetic analyses) despite their relevance for advancing the understanding of SES (e.g. Forbes, Gillson, and Hoffman 2018).

Technological development is rapidly expanding the ease and scope of ecological field data collection. Manual methods that are often costly in time and labour can now be augmented with or replaced by more automated techniques that collect objective, repeatable data in remote places, quickly and cost effectively (e.g. drones, camera traps, flux towers, acoustic arrays; see also Chapters 24 and 25). Machine learning can also be used to automate species identification (see Chapter 17). Many of these technological methods are becoming more viable options for research as the technology becomes more affordable and user friendly, and as required software becomes open access.

Some of these new approaches to data collection generate extremely large volumes of data. These big data challenges (see also Chapters 17 and 18) have facilitated the involvement of citizen 


\section{Case study 6.1: Land-sharing versus land-sparing to conserve ecosystem services: case studies from Ghana and India}

Agriculture currently covers $40 \%$ of the planet's ice-free terrestrial surface and the demand for agricultural products is expected to double by 2050 (Godfray et al. 2012). Although there are inevitable trade-offs between meeting this demand and the preservation of ecological functioning and ecosystem service provision (e.g. climate regulation, water purification, pollination), there is scope to reduce this trade-off by understanding how different species respond to different types of production landscapes.

This challenge led Green et al. (2005) to propose the land-sharing versus landsparing framework, where conservation and food production activities can either occur in the same space (land-sharing, e.g. conservation agriculture) or be separated in space (land-sparing, e.g. intensive farming with a portion of land set aside for protected areas). Green and colleagues suggested that whether land-sharing or landsparing was better for ensuring species persistence in a landscape would depend on how population densities of species change with agricultural yield. The trade-off between land-sharing and land-sparing can be modelled with a density-yield function, which demonstrates how the population density of an individual species in a landscape (number of individuals per unit area) changes according to the intensity of farming in the landscape (i.e. the yield per unit area of farmed land) (Green et al. 2005; Phalan et al. 2011). Individual species can be designated as 'winners' and 'losers' under the alternative strategies based on the shape of the curve (Figure 6.1).

In Figure 6.1, schematic (A) depicts the land-sharing versus land-sparing model where the area with the squiggly lines represents natural or protected land, the area with the diagonal dotted lines represents high-intensity agriculture and the area with the horizontal lines represents low-intensity agriculture or wildlife-friendly farming. The densities of species in this example are highest in an all-natural (i.e. no agriculture) scenario (B). However, if a set amount of agricultural yield is required from a given land area, either through land-sharing (low-intensity agriculture over the whole area) or through land-sparing (high-intensity agriculture over some of the area and natural land in the remainder of the area), the shape of the relationship between population density and agricultural intensity gives us insight into which strategy is better to conserve a species. The dotted line in (B) represents species that display near-to-natural-level population densities in a land-sharing scenario, making them well suited to this strategy. By contrast, the solid line represents species whose densities decline rapidly under any form of agriculture, even if it is low intensity. For these species, land-sparing is essential to provide the natural areas necessary for them to maintain their populations.

Phalan et al. (2011) collected data on population densities of birds and trees across landscapes in Ghana and India, using standard point count and plot-based survey techniques, respectively. Data on farm yield and profit were collected from household surveys and regressed against the population density of each species to produce the density-yield functions. Phalan et al. (2011) fitted density-yield functions that show how population 
(A)
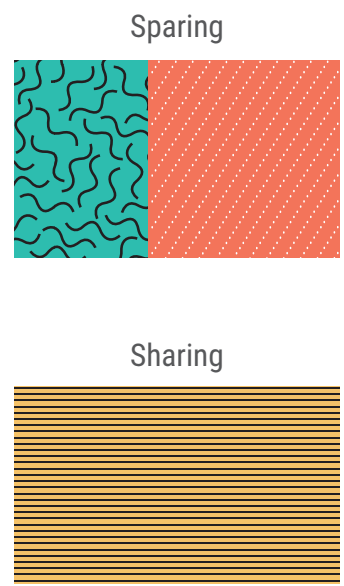

(B)

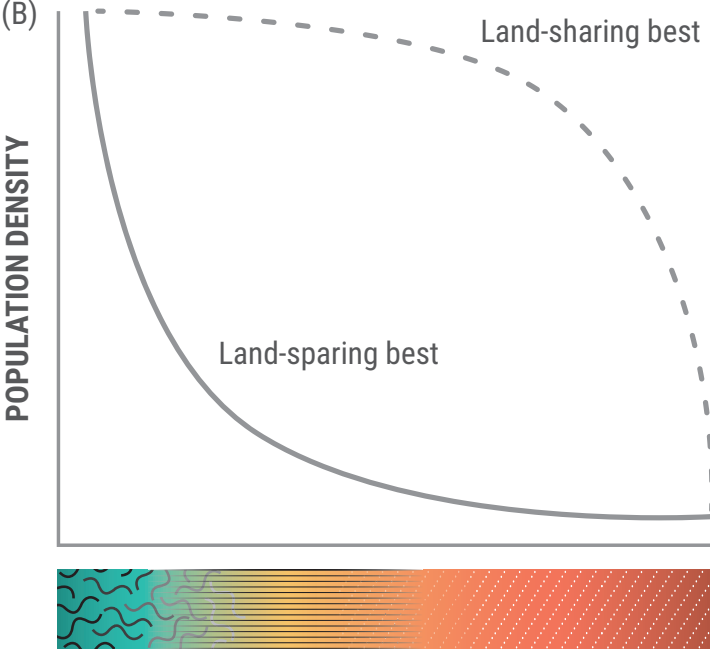

INCREASING AGRICULTURAL INTENSITY

Figure 6.1 A graphic representation of the density-yield function based on the landsparing versus land-sharing trade-off (๑ Chevonne Reynolds)

density changes with increasing agricultural yield for 167 bird and 220 tree species in Ghana, and 174 bird and 40 tree species in India for two types of agricultural yield currencies (food production and profit). Both study regions contained forest remnants within a matrix of farmland ranging from low-yielding (i.e. non-intensive) mosaic agriculture to large-scale high-yielding (i.e. intensive) monocultures. The researchers found that more species were negatively affected by agriculture than benefited from it. For both taxa in both countries, land-sparing was a more promising strategy for conserving species while minimising the negative impacts of food production.

Density-yield functions have become widely applied across multiple farming systems, from Uganda's banana-coffee arc to the Eurasian steppes (Hulme et al. 2013; Kamp et al. 2015), providing valuable insights into the potential for people to meet escalating food demand with the least harm to other species. Density-yield functions are therefore excellent examples of how ecological field data can be integrated with socio-economic data to address social-ecological problems. However, one limitation of this approach is the ability to gather agricultural yield data across large scales, which limits the scale at which the trade-off between the two land-use alternatives can be assessed. Novel approaches for quantifying agricultural yield, and for determining population densities of species at larger scales, will be needed if we wish to test this trade-off regionally or nationally. 
scientists to assist with analysis (e.g. Edgar et al. 2014), especially of camera- or video-trap data (zooniverse.org). Citizen scientists' enthusiasm has also been harnessed in large atlas projects (e.g. SABAP2), enabling the collection of extensive datasets. Using citizen science to collect ecological data presents a good opportunity to engage people in understanding the SES in which they and other citizens are embedded.

The increasing availability of open-access data has also facilitated the development of global datasets and the ability to do repeat field sampling via globally collaborative projects. The tropical tree database, for example, makes harvested biomass allometry across a suite of global tropical sites freely available (chave.ups-tlse.fr/pantropical_allometry.htm).

\section{Key readings}

Henderson, P.A. 2003. Practical Methods in Ecology. Malden: Blackwell Publishing.

Kent, M. 2011. Vegetation Description and Data Analysis: A Practical Approach. Hoboken: John Wiley and Sons.

Sala, O.E., R.B. Jackson, H.A. Mooney, and R.W. Howarth. 2000 Methods in Ecosystem Science. New York: Springer.

Wheater C.P., J.R. Bell, and P.A. Cook. 2011. Practical Field Ecology: A Project Guide. Hoboken: John Wiley and Sons.

\section{Acknowledgements}

We acknowledge funding from the Claude Leon Foundation and a Jennifer Ward Oppenheimer Research Grant (Hayley Clements), the DSI-NRF Centre for Invasion Biology (Karen Esler), the South African Research Chairs Initiative of the Department of Science and Technology and the National Research Foundation (NRF) of South Africa (grant 84379) (Penelope Mograbi), and an NRF Thuthuka grant (Chevonne Reynolds).

\section{References}

Addison, J., J. Davies, M. Friedel, and C. Brown. 2013. 'Do Pasture User Groups Lead to Improved Rangeland Condition in the Mongolian Gobi Desert?' Journal of Arid Environments 94: 37-46. doi:10.1016/j.jaridenv.2013.02.009.

Alexander, J., C.T. Downs, M. Butler, S. Woodborne, and C.T. Symes. 2018. 'Stable Isotope Analyses as a Forensic Tool to Monitor Illegally Traded African Grey Parrots.' Animal Conservation 1-10. doi:10.1111/acv.12445.

Andersson, E., S. Barthel, and K. Ahrné. 2007. 'Measuring Social and Ecological Dynamics Behind the Generation of Ecosystem Services.' Ecological Applications 17(5): 1267-1278. doi:10.1890/06-1116.1.

Chanda, R., O. Totolo, N. Moleele, M. Setshogo, and S. Mosweu. 2003. 'Prospects for Subsistence Livelihood and Environmental Sustainability along the Kalahari Transect: The Case of Matsheng in Botswana's Kalahari Rangelands.' Journal of Arid Environments 54(2): 425-445. doi:10.1006/ jare.2002.1100.

Cinner, J.E., C. Huchery, M. Aaron MacNeil, N.A.J. Graham, T.R. McClanahan, J. Maina, E. Maire et al. 2016. 'Bright Spots among the World's Coral Reefs.' Nature 535(7612): 416-419. doi:10.1038/ nature18607.

Cumming, G.S., and K. Maciejewski. 2017. 'Reconciling Community Ecology and Ecosystem Services: Cultural Services and Benefits from Birds in South African National Parks.' Ecosystem Services 28: 219-227. doi:10.1016/j.ecoser.2017.02.018.

Curtin, R., and R. Prellezo. 2010. 'Understanding Marine Ecosystem Based Management: A Literature Review.' Marine Policy 34(5): 821-830. doi:10.1016/j.marpol.2010.01.003. 
Daw, T.M., J. Robinson, and N.A.J. Graham. 2011. 'Perceptions of Trends in Seychelles Artisanal Trap Fisheries: Comparing Catch Monitoring, Underwater Visual Census and Fishers' Knowledge.' Environmental Conservation 38(1): 75-88. doi:10.1017/S0376892910000901.

De Knegt, H.J., F. van Langevelde, A.K. Skidmore, A. Delsink, R. Slotow, S. Henley, G. Bucini et al. 2011. 'The Spatial Scaling of Habitat Selection by African Elephants.' Journal of Animal Ecology 80(1): 270-281. doi:10.1111/j.1365-2656.2010.01764.x.

Dearing, J.A., X. Yang, X. Dong, E. Zhang, X. Chen, P.G. Langdon, K. Zhang, W. Zhang, and T.P. Dawson. 2012. 'Extending the Timescale and Range of Ecosystem Services through Paleoenvironmental Analyses, Exemplified in the Lower Yangtze Basin.' Proceedings of the National Academy of Sciences 109(18): E1111-20. doi:10.1073/pnas.1118263109.

Edgar, G.J., A.E. Bates, T.J. Bird, A.H. Jones, S. Kininmonth, R.D. Stuart-Smith, and T.J. Webb. 2016. 'New Approaches to Marine Conservation Through the Scaling Up of Ecological Data.' Annual Review of Marine Science 8(1): 435-461. doi:10.1146/annurev-marine-122414-033921.

Edgar, G.J., R.D. Stuart-Smith, T.J. Willis, S. Kininmonth, S.C. Baker, S. Banks, N.S. Barrett et al. 2014. 'Global Conservation Outcomes Depend on Marine Protected Areas with Five Key Features.' Nature 506(7487): 216-220. doi:10.1038/nature13022.

Forbes, C.J., L. Gillson, and M.T. Hoffman. 2018. 'Anthropocene Shifting Baselines in a Changing World: Identifying Management Targets in Endangered Heathlands of the Cape Floristic Region, South Africa.' Anthropocene 22: 81-93. doi:10.1016/j.ancene.2018.05.001.

Fry, B. 2006. Stable Isotope Ecology. New York: Springer.

Genkai-Kato, M., and S.R. Carpenter. 2005. 'Eutrophication Due to Phosphorus Recycling.' Ecology 86(1): 210-219. doi:10.1890/03-0545.

Godfray, H.C.J., J.R. Beddington, I.R. Crute, L. Haddad, D. Lawrence, J.F. Muir, J. Pretty, S. Robinson, S.M. Thomas, and C. Toulmin. 2012. 'Food Security: The Challenge of Feeding 9 Billion People.' Science 327: 812-819. doi:10.1126/science.1185383.

Green, R.E., S.J. Cornell, J.P.W. Scharlemann, and A. Balmford. 2005. 'Farming and the Fate of Wild Nature.' Science 307(5709): 550-555. doi:10.1126/science.1106049.

Hebblewhite, M., and D.T. Haydon. 2010. 'Distinguishing Technology from Biology: A Critical Review of the Use of GPS Telemetry Data in Ecology.' Philosophical Transactions of the Royal Society B: Biological Sciences 365(1550): 2303-2312. doi:10.1098/rstb.2010.0087.

Henderson, P.A. 2003. Practical Methods in Ecology. Malden: Blackwell Publishing. doi:10.1111/ j.1442-9993.2005.01460.x.

Hong, S.H., B.H. Han, S.H. Choi, C.Y. Sung, and K.J. Lee. 2013. 'Planning an Ecological Network Using the Predicted Movement Paths of Urban Birds.' Landscape and Ecological Engineering 9(1): 165-174. doi:10.1007/s11355-012-0194-3.

Hulme, M.F., J.A. Vickery, R.E. Green, B. Phalan, D.E. Chamberlain, D.E. Pomeroy, D. Nalwanga et al. 2013. 'Conserving the Birds of Uganda's Banana-Coffee Arc: Land Sparing and Land Sharing Compared.' PLoS ONE 8(2): e54597. doi:10.1371/journal.pone.0054597.

Johansson, Ö., T. McCarthy, G. Samelius, H. Andrén, L. Tumursukh, and C. Mishra. 2015. 'Snow Leopard Predation in a Livestock Dominated Landscape in Mongolia.' Biological Conservation 184: 251-258. doi:10.1016/j.biocon.2015.02.003.

Jouffray, J-B., M. Nystrom, A.V. Norstrom, I.D. Williams, L.M. Wedding, J.N. Kittinger, and G.J. Williams. 2014. 'Identifying Multiple Coral Reef Regimes and Their Drivers Across the Hawaiian Archipelago.' Philosophical Transactions of the Royal Society B: Biological Sciences 370: 2013026820130268. doi:10.1098/rstb.2013.0268.

Kamp, J., R. Urazaliev, A. Balmford, P.F. Donald, R.E. Green, A.J. Lamb, and B. Phalan. 2015. 'Agricultural Development and the Conservation of Avian Biodiversity on the Eurasian Steppes: A Comparison of Land-Sparing and Land-Sharing Approaches.' Journal of Applied Ecology 52(6): 1578-1587. doi:10.1111/1365-2664.12527.

Kemp, J., A. López-Baucells, R. Rocha, O.S. Wangensteen, Z. Andriatafika, A. Nair, and M. Cabeza. 2019. 'Bats as Potential Suppressors of Multiple Agricultural Pests: A Case Study from Madagascar.' Agriculture, Ecosystems and Environment 269: 88-96. doi:10.1016/j.agee.2018.09.027.

Kent, M. 2011. Vegetation Description and Data Analysis: A Practical Approach. Hoboken: John Wiley and Sons.

Kress, W.J., C. Garcia-Robledo, M. Uriarte, and D.L. Erickson. 2015. 'DNA Barcodes for Ecology, Evolution, and Conservation Orogen.' Trends in Ecology and Evolution 30(1): 25-35. doi:10.1016/j. tree.2014.10.008. 
Mandle, L., T. Ticktin, and P.A. Zuidema. 2015. 'Resilience of Palm Populations to Disturbance is Determined by Interactive Effects of Fire, Herbivory and Harvest.' Journal of Ecology 103(4): 10321043. doi:10.1111/1365-2745.12420.

Miguel, E., V. Grosbois, H. Fritz, A. Caron, M. de Garine-Wichatitsky, F. Nicod, A.J. Loveridge, B. Stapelkamp, D.W. Macdonald, and M. Valeix. 2017. 'Drivers of Foot-and-Mouth Disease in Cattle at Wild/Domestic Interface: Insights from Farmers, Buffalo and Lions.' Diversity and Distributions 23(9): 1018-1030. doi:10.1111/ddi.12585.

Minnie, L., A. Zalewski, H. Zalewska, and G.I.H. Kerley. 2018. 'Spatial Variation in Anthropogenic Mortality Induces a Source - Sink System in a Hunted Mesopredator.' Oecologia 186(4): 939-951. doi:10.1007/s00442-018-4072-z.

Mintzer, V.J., A.R. Martin, V.M.F. da Silva, A.B. Barbour, K. Lorenzen, and T.K. Frazer. 2013. 'Effect of Illegal Harvest on Apparent Survival of Amazon River Dolphins (Inia geoffrensis).' Biological Conservation 158: 280-286. doi:10.1016/j.biocon.2012.10.006.

Nordlund, L., J. Erlandsson, M. de la Torre-Castro, and N. Jiddawi. 2010. 'Changes in an East African Social-Ecological Seagrass System: Invertebrate Harvesting Affecting Species Composition and Local Livelihood.' Aquatic Living Resources 23(4): 399-416. doi:10.1051/alr/2011006.

Nyström, M., N.A.J. Graham, J. Lokrantz, and A.V. Norström. 2008. 'Capturing the Cornerstones of Coral Reef Resilience: Linking Theory to Practice.' Coral Reefs 27(4): 795-809. doi:10.1007/ s00338-008-0426-z.

Perez, L., K. Eun-kyeong, and R. Sengupta. 2018. Agent-Based Models and Complexity Science in the Age of Geospatial Big Data. Cham: Springer Nature. doi:10.1007/978-3-319-65993-0.

Phalan, B., M. Onial, A. Balmford, and R.E. Green. 2011. 'Reconciling Food Production and Biodiversity Conservation: Land Sharing and Land Sparing Compared.' Science 333(6047): 1289-1291. doi:10.1126/science.1208742.

Pressey, R.L., P. Visconti, and P.J. Ferraro. 2015. 'Making Parks Make a Difference: Poor Alignment of Policy, Planning and Management with Protected-Area Impact, and Ways Forward.' Philosophical Transactions of the Royal Society of London. Series B, Biological Sciences 370: 20140280. doi:10.1098/ rstb.2014.0280.

Quinn, G.P., and M.J. Keough. 2002. Experimental Design and Data Analysis for Biologists. Cambridge: Cambridge University Press.

Read, Z.J., H.P. King, D.J. Tongway, S. Ogilvy, R.S.B. Greene, and G. Hand. 2016. 'Landscape Function Analysis to Assess Soil Processes on Farms Following Ecological Restoration and Changes in Grazing Management.' European Journal of Soil Science 67(4): 409-420. doi:10.1111/ejss.12352.

Sala, O.E., R.B. Jackson, H.A. Mooney, and R.W. Howarth. 2000. Methods in Ecosystem Science. New York: Springer.

Smith, D.G. 1987. 'A Mini-Vibracoring System.' Journal of Sedimentary Research 57(4): 757-758.

Sutaria, D. 2009. 'Species Conservation in a Complex Socio-Ecological System: Irrawaddy Dolphins, Orcaella Brevirostris in Chilika Lagoon, India.' PhD diss., James Cook University.

Swemmer, A.M., M. Mashele, and P.D. Ndhlovu. 2019. 'Evidence for Ecological Sustainability of Fuelwood Harvesting at a Rural Village in South Africa.' Regional Environmental Change 19: 403-413. doi:10.1007/s10113-018-1402-y.

Tan, K.H. 2005. Soil Sampling, Preparation, and Analysis. Boca Raton: CRC Press.

Ticktin, T., A.N. Whitehead, and H. Fraiola. 2006. 'Traditional Gathering of Native Hula Plants in Alien-Invaded Hawaiian Forests: Adaptive Practices, Impacts on Alien Invasive Species and Conservation Implications.' Environmental Conservation 33(3): 185-194. doi:10.1017/S0376892906003158.

Tongway, D., and N. Hindley. 2004. 'Landscape Function Analysis: A System for Monitoring Rangeland Function.' African Journal of Range and Forage Science 21(2): 109-113. doi:10.2989/10220110409485841.

Villasante, S. 2012. 'The Management of the Blue Whiting Fishery as Complex Social-Ecological System: The Galician Case.' Marine Policy 36(6): 1301-1308. doi:10.1016/j.marpol.2012.02.013.

Ward, D.F.L., S. Wotherspoon, J. Melbourne-Thomas, J. Haapkylä, and C.R. Johnson. 2018. 'Detecting Ecological Regime Shifts from Transect Data.' Ecological Monographs 88(4): 694-715. doi:10.1002/ecm.1312.

Wheater, C.P., J.R. Bell, and P.A. Cook. 2011. Practical Field Ecology: A Project Guide. Hoboken: John Wiley and Sons.

Wu, J., W. Shen, W. Sun, and P.T. Tueller. 2002. 'Empirical Patterns of the Effects of Changing Scale on Landscape Metrics.’ Landscape Ecology 17(8): 761-782. doi:10.1023/A:1022995922992. 